\title{
The Cultivation of Cross-border Professional Talents in Yunnan Province based on the Neighborhood Partnership Strategy
}

\author{
NingYan \\ International Business School \\ Yunnan University of Finance and Economics \\ Kunming, China \\ ningyan68@126.com
}

\begin{abstract}
In the construction of the China - Indo - China Peninsula and the BCIM International Economic Cooperation Corridor and the implementation of the One Belt and One Road initiative, Yunnan, with its special geographical advantages and regional features, is undertaking an important mission, in which talent cultivation is a prerequisite. The cultivation modes of professional talents in Yunnan University of Finance and Economics, based on the Neighborhood Partnership Strategy and catering to the needs of South and South-east Asian countries, have harvested fruits after several years'construction and development. Through a worthwhile attempt, it has provided a vivid case of the reform and innovation of international cultivation concepts, aims and modes as far as postgraduate education is concerned.
\end{abstract}

Key words—neighborhood partnership strategy; cross-border professional talents; innovative cultivation modes

\section{INTRODUCTION}

In the background of further construction of CAFTA and GGMS, quicker promotion of Yunnan Bridgehead Strategy and wider influence of One Belt \& One Road Initiative, enhancing and expanding the neighborhood Partnership Strategy between china and surrounding countries, which is characterized by trust \& friendship, cooperation \& mutual benefit and openness \& inclusiveness, has been proved to be the strategic measures to meet the opportunities and challenges of globalized and regionalized economy. Located in a leading position, Yunnan plays a special part in the political, economic and cultural communications between China and South \& Southeast Asian countries. Education, especially higher education, serving as a basic part to guarantee the quality and the human recourse reserves in the social and economic development, is being offered important opportunities to give a full play of its social service, reform and innovation functions. In 2006 when Yunnan Provincial Party Committee and Yunnan Provincial Government issued The Proposals on Speeding Up the Implementation of the Going Out Strategy in Colleges and Universities and Improving the Level of Internationalization of Higher Education, Yunnan higher education internalization has been upgraded to a strategic height which is aimed at helping build a harmonious and peaceful surrounding environment, expanding foreign economic cooperation \& exchange between Yunnan and neighboring counties, enhancing Yunnan's international status, economic level and comprehensive competitiveness as well as promoting its higher education reform. In the same year, Yunnan Provincial Education Department began to implement the Proposals with the concrete measures which focused on accelerating the steps of Yunnan higher education internationalization based on the surrounding environment and the demand of the outside world. In 2011, in response to the requirements of the Central Government about the Construction of Yunnan as the Bridgehead of China Facing the Southwest Areas, Yunnan Provincial Education Department proposed One Home and Three Platforms as new strategic concepts to promote higher education internalization.

Thus, based on the special geographical, economic, cultural and regional advantages of Yunnan, cultivating professional talents who are characterized by international awareness, knowledge and communicative skills will cater to the need of labor markets in South \& Southeast Asia.[1] It is not only the urgent requirements of speeding up the GMS cooperation, promoting the construction of Yunnan Bridgehead, but also the practical measures to deepen the construction of China - SEAN Free Trade Zone and in response to One Belt and One Road Initiative and other challenges and opportunities at the present. In view of the fact that the concept, method, quality, scale and quantity of current professional talent cultivation facing South \& Southeast Asian couldn't meet the demand, setting forth a systematic and comprehensive study which focuses on the reform of educational concepts as well as the innovation of cultivation modes, carrying on case studies and providing the consultation based on theoretical and practical researches to the governments and management departments of higher education will have a far-reaching influence. 


\section{THE STRATEGIC BACKGROUND OF CROSS-BORDER}

\section{Professional TALENT CULTIVATION}

In 2008, Greater Mekong Sub-regional Economic Corridor Forum was established in Kunming. With the construction of Two Vertical and Three Horizontal transport channels as a base, the economic corridor is developing fast into an economic belt of a comprehensive unit of industries, trades and infrastructures. Yunnan possesses not only the on-shore advantages of the communications between the Pacific Ocean and the India Ocean, but also an access to the three largest markets in mainland China, South Asia and Southeast Asia, which shows its regional advantages in the commercial corporation with ASEAN. In the construction and development of the China - ASEAN Free Trade Zone, Yunnan has established a dominate position in taking shape of the three-dimensional traffic pattern as Highway, Water, Aviation Combined Transport; East, Middle and West Channels Linking ASEAN. Furthermore, the Long-term friendship and cooperation between Yunnan and ASEAN countries offer Yunnan precious chances to play an effective role in the construction of China - ASEAN Free Trade Zone.

In 2010, China clearly put forward the strategic plan of constructing Yunnan as an important bridgehead facing Southwestern regions. The strategy not only builds an important platform on which Yunnan could further tap its own advantages and give full play of its roles as a pioneer and leader in the process of the opening up Southwestern China, but also put forward new requirements of seeking more policy and financial support from the central government and eventually form a new pattern based on Yunnan, with Kunming as the center facing South \& Southeast Asia.

In 2014, President Xi Jinping pointed out at the CICA Summit that China will work with other countries to accelerate the development of the Silk-Road Economic Zone and the construction of the Maritime Silk Road of the Twentyfirst Century, be more involved in the process of regional cooperation and promote development and security in Asian countries. In One Belt and One Road initiative, Yunnan will play a more important role as a fulcrum in the China - South Asia - West Asia Economic Belt and as a strategic channel to maintain the good - neighbor diplomacy.

In 2015, with Friendship, Understanding, Mutual Trust and Win-Win Cooperation as its theme, the 4th China - South Asia Expo was held in Kunming. Li Yuanchao, Vice President of China, pointed out in his speech that China would uphold the concept of Friendship, Understanding, Mutual Trust and Win-Win Cooperation, deepen mutually beneficial cooperation with South Asia, create a community with a common destiny to share peace $\&$ danger and prosperity \& recession. China will adhere to the belief of mutual dependence, interconnection \& intercommunication, and promote the construction of the Sino - India - Burmar Economic Corridor, the Sino - Pakistan Economic Corridor as well as Greater Mekong sub regional economic cooperation. Li jiheng, Secretary of the Yunnan Provincial Party Committee, pointed out in his speech that Yunnan would make full use of its advantages of location and resources, practice a opener policy, promote the construction of international transportation channels with neighboring countries, and step onto a new stage of the economic cooperation in the Greater Mekong sub-regions.

In summary, Yunnan is in an era of economic take-off, cultural upgrading and social development, which will surely bring about precious opportunities and challenges. Yunnan has to not only respond to the country's strategic decisions, but also give a full play to its own advantages, potentials and initiatives. Among all the measures to be taken to seize the opportunities and meet the challenges, one is to cultivate a number of cross-border professional talents who are familiar with China (Yunnan) affairs, have international perspectives, solid professional knowledge, good language capability and cultural communication skills, as well as academic attainments and rich practical experience. Those people could go deep into the frontiers where political and economic exchanges, cultural communications and social interactions are happening every day, work as a bridge and a tie to coordinate, communicate and deal with related issues, and help to realize the transformation of a single business or foreign languages (minor languages of Southeast Asia) processional to a compound processional talent; Those measures will finally provide adequate human resources to satisfy the demand of Yunnan's strategy aimed at the wider and deeper communication and cooperation with South \& Southeast Asian countries.

As far as the current situations of higher education in China are concerned, developed provinces lack of the drive to innovate the talent cultivation modes based on geographical advantages to meet the need of South \& Southeast Asia oriented labor markets, while the underdeveloped provinces lack of relevant policies, financial support and innovative spirit. The above two phenomena show the fact that there is a big gap between the existing cross-border talent cultivation modes and compound talents required by the national strategy. The structural shortage of the human resources aiming at the demands of South \& Southeast Asian countries as well as the comparatively poor quality and low quantity of the talents have become increasingly serious. Therefore, updating the South \& Southeast Asia - oriented talent cultivation concepts, innovating corresponding cultivation modes, training more compound international talents of high-quality have already become the urgent mission of the present.

\section{AN ANALYSIS OF THE MARKET DEMAND FOR THE CROSS -}

\section{BORDER PROFESSIONAL TALENTS}

\section{A. Economic and Trade Cooperation between China and} South \& Southeast Asia Growing Significantly with Ever Bigger Market Proportion

During 1997-2011, the scale of bilateral trades between Yunnan and South \& Southeast Asian countries have been expanding and the growth rate has been significantly accelerated. The trades with ASEAN increased by 15 times, and with South Asia increased by 38 times. In the past 15 years, Yunnan has trading partnership with all the countries in South \& Southeast Asia, and diversified market patterns have been partially formed. The rapid growth of bilateral exchanges as well as economic and trade cooperation between Yunnan and the neighboring countries have put forward new, higher requirements for the quality and reserves of professional talents.

\section{B.A Big Gap between Cross-Border Professional Talent Reserves and the Market Demand}

In response to Several Proposals on Accelerating the Implementation of the Going Out Strategy and Improving the International Level of Higher Education issued by Provincial Government of Yunnan Provincial Party committee, almost all of the undergraduate colleges and universities in Yunnan have set up minor languages majors catering to ASEAN / Southeast Asia / South Asia. In spite of the different schooling orientations, diversified cultivation modes, different curriculum, it is widely acknowledged that the reform of higher education internationalization should be interpreted as Seizing Historical Opportunities, Making Use of Regional 
The First International Symposium on Business Cooperation and Development in South-East and South Asia under B\&R Initiative (ISBCD-16) Advantages, Playing a Leading and Exploratory Role, and Occupying Talent Cultivation platform. There is no doubt that in the past 20 years the higher education internationalization in Yunnan based on Neighborhood Partnership Strategy has made some achievements, which has alleviated the contradiction between the current talent reserves and the international market demand to a certain extent, and has been playing a positive role in promoting cultural exchanges and cooperation between Yunnan and neighboring countries. A large number of empirical studies, however, have shown that there are still a lot of problems to be addressed and updated as far as the concepts and cultivation modes are concerned.

1) Some colleges and universities lack of adequate market research on the quantity, quality and types of talents needed. Some of them even rushed to run a program without feasibility analysis, appropriate teaching facilities and qualified educational resources. Consequently, those facts have resulted in the concerns that the school-running orientations are not clear, the cultivation features are not distinct and the curriculum planning has loose connection with the cultivation aims.

2) Due to the vague school-running orientations, there appear many problems, for example, the cultivation aims are vague, the cultivation patterns are identical and the curriculum is short of systematic and pertinent planning.

3) Owing to the restriction of the objective factors such as the faculty's quality and students' sources, it is difficult to combine language learning, professional knowledge teaching and professional skill training in the teaching process, which has resulted in the fact that the talent cultivation results couldn't be up to the standards set for compound professionals and meet the needs of the market.

In summary, cross-border higher education based on the Neighborhood Partnership Strategy in Yunnan has expanded on scale to some extent in recent years. But the education quality and schooling level are relatively low and lack of competitiveness in the international cultural exchanges and trade cooperation. There are some teachers of minor languages once describing that their students were welcome as "a favorite" and reserved by some foreign trade oriented companies even before they graduate. Not long after their taking the job, however, they were not found capable of working independently and meeting the expectations of the company. Some senior administrators once said that many schools nowadays had set up minor languages courses, but of low quality while with very large scale. The teaching quality could not be guaranteed, and the graduates couldn't acquire proper, adequate and applied knowledge and skills to undertake related work. They are ignorant of international trade environment, such as political, commercial and cultural characteristics of local places. Most of them could hardly finish the translating or clerical assignments related to international trade [2].

\section{INNOVATION OFCROSS-BORDERTALENTCULTIVATION}

As mentioned above, the level, quality and scale of crossborder talent cultivation in Yunnan appear to be unsustainable in response to the opportunities and challenges of present social, economic and cultural development. Nowadays, China's higher education has been transformed from the SoleBridge elite education at the beginning of reform and opening up policy to mass education nowadays. In July 2013, Liu Yandong, Vice Premier of China, pointed out at the National Conference on Graduate Education that the management departments and concerned people of postgraduate education, the top-level of the national education, must have a clear understanding of the current Chinese educational situation, make a scientific judgment about the international phenomenon from international perspectives, have an accurate grasp of the trend in the view of history, maintain a strong awareness of the mission undertaken and fully understand the importance and urgency of deepening the reform of postgraduate education and improving its quality. In recent years, many colleges and universities in China have established the concept of postgraduate education internationalization, which consciously determines its orientation and concrete measures from international perspectives. [3] This education mode is not only the innovation of the cultivation methods, but all the more of cultivation concepts. Taking the reform and innovation of professional master's cultivation mode in Yunnan University of Finance and Economics (YUFE) as an example, this paper is to discuss the relevant issues.

YUFE is the first university in Yunnan to undertake Sino - Foreign cooperative education programs. Yin Hong, vicepresident of YUFE, said to the press in 2105 that the university's higher education internationalization has developed gradually from cautious attempt to the active and bold offering of the olive branch. In the past over thirty years, YUFE's higher education internationalization has seen geometric increase and changes. The higher education internationalization in YUFE has expanded from the undergraduate level at beginning to postgraduate level at present, from the Inward Introduction in the past to the Outward Promotion nowadays, and has made remarkable achievements and sustainable development. International Business School (IBS) of YUFE is a teaching unit that runs the Sino-Foreign undergraduate and postgraduate cooperation programs with oversea universities under the leadership of YUFE. Approved by the Academic Degrees Committee of the State Council, the Ministry of Education of China and the Education Department of Yunnan Province, IBS is cooperating with universities in USA, Australia and UK to run double bachelor degree programs, and with the University of Greenwich, UK to run postgraduate programs. Among five postgraduate programs run by IBS, three of them are enrolling students on the basis of the national admission examination. They are Management Science \& Engineering, International Business, and Engineering (Project Management). The other two are cooperative programs with the University of Greenwich, UK. They are Project Management and Real Estate. In addition, IBS has various academic research platforms, including the International Business Officer's Research \& Studies Base of Ministry of Commerce, Management and Public Service Information Engineering Research Center of Yunnan Province, and Internationalized Higher Education Research Station of Yunnan Province. Authorized by YUFE, IBS also sponsors the Bangkok Business School in Thailand and Panyapiwat Institute of Economic Management.

The paper will make a case study of the reform and innovation of cross-border talent cultivation in YUFE as far as the school-running orientation and talent cultivation chain are concerned.

\section{A. Accurate Schooling Orientation and Distinct Cultivation Features}

Promoting the international exchange and cooperation in the field of postgraduate education, taking measures to speed up the pace of China's postgraduate education to be involved into the outside world and further expanding the influence of postgraduate education in the world [4] is one of the goals of China's postgraduate education development in the first ten years of the twenty-first Century. Among them, promoting the international competitiveness of postgraduate education, cultivating professional talents with a solid academic 
The First International Symposium on Business Cooperation and Development in South-East and South Asia under B\&R Initiative (ISBCD-16) foundation, a keen international perspective, adaptable to the opportunity and challenge of globalization are general requirements for improving the quality of postgraduate education in China.

\section{1) Full Market Survey}

At the beginning of 2014, a new round of application for professional master degree accreditation started. With the IBS as the core unit, YUFE effectively integrated the advantages of the related schools and institutions and was successfully granted the Master Degree Accreditation of Project Management (Engineering). From the very start of the application, YUFE made a full market survey of demand of the project management talents and drew the following conclusions.

Through an analysis of the demand for management talents in overseas project investment, at least additional 30 professionals are needed each year. Through an analysis of the demand of project management talents in overseas project contracting, at least additional 60 relevant professionals are needed each year. Through an analysis of the demand for management talents in cross-border information engineering, at least additional 20 relevant professionals are needed each year. Through the analysis of the demand for project management talents in overseas foreign aid projects, at least additional 10 relevant professionals are needed each year. Through an analysis of the curriculum of Project Management in other colleges and universities in Yunnan, it is found that no matter what quantity or quality they have, the current talent reserves cannot satisfactorily meet the needs of the exportoriented economic development in Yunnan [5].

Based on the previous detailed investigation as well as the objective and scientific argumentation of the talent market demand, YUFE established the cultivation orientation. That is to integrate the advantages and resources of relevant governments and enterprises, adopt condensed cultivation chain, and focus on the international and applied characteristics of Project Management (Engineering) postgraduate education to meet the need of regional talent market.

\section{2) Clear Cultivation Aims}

Based on the school-running orientation, YUFE set up the clear cultivation aims. That is to cultivate compound and applied project management talents who are specialized in international project decision-making, planning, implementation, assessment and life management. The graduates of this major are expected to have a solid theoretical foundation and profound practical knowledge in this field, be aware of the development trend of project management at home and abroad, independently engage in international project planning and evaluation, financing, risk management, human resources and communication management, have foreign language proficiency, a broad international perspective and a qualified international working background [5].

Based on the cultivation aims, YUFE adopts the standards and requirements of concepts of internationalized curriculum planning. That is to introduce international education resources, reflect the advantages of the international education program, enhance students' professional capability, carry on the internship in the cross-border enterprises and realize perfect connection between talent cultivation and future career [5].

\section{3) Innovation of Cultivation Modes}

Based on the cultivation aims and curriculum, YUFE has updated the cultivation mode. That is to develop a compound teaching mode of University-Government-Enterprise-Social

organizations, highlight its international, professional and customized features, construct the compound platform of producing, learning and researching, seek the help from governments, enterprises and social organizations to support and finance the students' professional internship, invite senior entrepreneurs as an off-campus tutors to form the DoubleTutored supervision system and finally realize a perfect combination of theory and practice. During the process, YUFE collaborate with governments, enterprises and social organizations to develop three mechanisms: customized cultivation mechanism, vocational certificate incentive mechanism and professional internship mechanism in order to develop a whole and complete cultivation chain of highquality talents to fully meet the needs of the society [5].

\section{B. Taking Employment as the Orientation, Highlighting} Cultivation Features, and Improving the Competitiveness of Talents

According to the Opinions on Deepening the Reform of the Cultivation Mode of Professional Degree Postgraduates issued by the Ministry of education and the Ministry of Human Resources \& Social Security, which put emphasize on labor market orientation, practical ability focus, combined methods of producing and learning, the postgraduate education in China should develop an innovative cultivation mode to keep pace with the economic and social development and fully reflect the distinct Chinese features. YUFE has updated curriculum planning and strengthen professional ability training in order to cultivate the professional business talents who adapt to local economic development, adopting an international perspective and possessing applied knowledge.

YUFE is one of the first universities to be approved the Professional Master Degree Accreditation in international business, who started its first enrollment in 2011. Ever since 2013 when the first students were going to carry on their professional internship, IBS has held four rounds of overseas internships which are characterized by a wide range, good effect and big social impact. The featured internships are commented as Pioneering in Yunnan's Universities, Comprehensively Innovating Application - Oriented Talent Training Mode by some well-known domestic media. YUFE sent 10 postgraduate students in 2013, 6 in 2014, and 9 in 2015 to carry on their three-month overseas internships in the business representative offices of Project Department of Yunnan Construction Engineering Group, China Water Conservancy and Hydro-power Fourteenth Engineering Bureau and other enterprises located in Laos, Kampuchea, Malaysia, Sri Lanka, Burma, and Thailand.

The above overseas professional internships are a pioneering attempt to innovate the professional master's cultivation mode, which have accumulated valuable experience and made gratifying practical achievements.

1) Opening up the second classroom. During this vivid, practical and more effective second classroom, the students' horizon has been broadened, their learning methods became more flexible and the effective combination of textbook knowledge and practical experience was realized. In addition, the first-hand information and materials of the international business in South \& Southeast Asian countries gathered in the internships have greatly enriched the teaching content of the major and provided valuable data for academic research.

2) Harvesting practical experience. Duringthe internships the students participated in the whole process of international business activities, and made big progress in the aspects of maturity, openness, discipline, team work and etc. 
The First International Symposium on Business Cooperation and Development in South-East and South Asia under B\&R Initiative (ISBCD-16)

3) Innovating cultivation modes. These activities have tested the innovative cultivation mode of GovernmentUniversity-Enterprise combination, facilitated the connection between the classroom education and future career. These activities have attached importance to practice, the integration of local economic development and the higher education's orientation. These activities have help universities and colleges to facilitate the process of transporting specialized talents to serve the local economy and finally realize the aims and values of high education [6].

\section{Going out Strategy in the Cultivation of Cross-}

\section{BORDER TALENTS}

Among the basic functions of higher education, the social service is always the main force to transform theoretical knowledge into practical productivity and finally promote social, economic and cultural development. Similarly, the implementation of innovation - driven development strategy and enhancement of higher education's service function are the urgent need of local economic and educational development in Yunnan, just as ZhuHuashan, ViceCommissioner of Yunnan Education Department, put it in 2015 at the Speech Addressing to Leading Cadres of the Provincial-Level Universities. Innovative reform and promotion of the social service function of the postgraduate education in YFEE are carried out, on the one hand, by the cultivation of cross-border talents who are familiar with international business of China, Yunnan, and most of all of South \& South-east Asian countries; and, on the other hand, by the realization of effective joint between the cultivation of Outward-Oriented (overseas) Chinese talents and InwardOriented (Chinese/Yunnan) foreign talents. This effective joint, functioning as high quality lubricant, will more directly and effectively promote and enhance the economic and cultural exchanges between China (Yunnan) and neighboring countries.

In 2014, YUFE applied for 2015-18 Master-degree Program of International Business in Developing Countries sponsored by the Ministry of Commerce of China. In September of 2015, the first 20 students from 7 countries entered the university as scheduled. The target students of the program are mainly from South \& Southeast Asia, Oceania and other developing countries. The students are expected to be involved in the education aiming to cultivate high-level, compound and applied professional talents in the fields of infrastructure construction, real estate development and management, project investment \& finance and some other management departments concerning public construction.

\section{A. Market Demand Analysis}

Developing countries are always densely populated areas, with relatively backward economic and social development, but rich resources. These countries are highly complementary with China in their economic and industrial structures. In particular, Southeast Asian countries adjacent to Yunnan Province with very important strategic locations are important

\section{B. Flexible and Diversified Cultivation Modes[7]}

According to the appliedfeatures of professional postgraduate cultivation, the program pays special attention to the combination of theory and practice, emphasizes the combination of accumulation of knowledge, skill training and comprehensive quality development, and highlights the case study and practices. The curriculum planning is to fully realizethe supporting role of classroom knowledge to pave a good way betweenthe courses and the subsequent professional internship, dissertations, and career. During the classroom channels for China to communicate with India Ocean and the Middle East. In recent years, China's overseas investment and construction contracting projects have undergone a rapid development, with annual growth rate of more than $20 \%$. More than $70 \%$ of these projects are located in Africa, Southeast Asia, South Asia, South America and other developing countries. In the face of the introduction of a large number of Chinese projects, some management and technical staff in those countries have found it difficult to meet the requirements of the projects in a short time due to cultural differences, unsynchronized professional technology and other objective barriers. In particular, the unawareness and misunderstanding of some foreign senior management officials about the relevant issues and problems often lead to management inefficiency and even hostility of local enterprises towards China.

Based on the above analysis, YUFE has set up the cultivation orientation supported by the training of high-level professionals in the field of project management to better promote the development of various types of Chinese investment and contracting projects in developing countries, achieve sustainable development and achieve good economic and social profits in local areas, in order to ensure the implementation of Yunnan Bridgehead and One Belt and One Road Initiative and to deepen the relationship with those developing countries in all aspects.

\section{Feasible Enrollment Approaches[7]}

This educational program is characterized by a wide range of student sources and complicated foreign enrollment procedures. The annual enrollment plan is arranged by Foreign Aid Division of Ministry of Commerce Department Of China and is implemented by joint work of relevant departments. The specific enrollment is mainly carried out by the open promotion of the Embassy Commercial Counselor's Office, with Ministry of Commerce (Yunnan) International Business Officer Training Center and YUFE as the project undertaking organizations.

In order to ensure the quality of enrollment, reduce the loss of students, the programadopts the year-round enrollment. The specific work is promoted by the Embassy Commercial Counselor's Office to the recipient countries: issuing enrollment brochures---recommendingcandidates to the management department---selecting candidates to be the potential trainees--- recommendingpotential trainees to the training unit---the training unit selectingthe academicsupervisor---supervisor and trainee establishing contact--- supervisor being in charge of the academic work even before the enrollment.

Priority of being trained is given to the officials who have direct business relations with overseas China-invested enterprises. Due to the fact that these officials have a close observation and a personal understanding of the Chinese enterprises, they will more likely offernecessary and instant help to Chinese enterprises transform the achievements of the trainingto their practical work and consequently make commitment to theoperations of overseas Chinese enterprises in their own countries.

teaching process, the teachers adopt the practical teaching methods of case analysis, group discussion and enterprise visiting; the teachers adopt small-classroom teaching with more than 15 but less than 20 students in each class. If the studentsare less than 5 in one class, the program will arrange the students for studying together with local postgraduate students, which will help developtheir team spirit and ability of cross-cultural communication, academic exchanges, and emotional communication between Chinese students and themselves. 


\section{CONCLUSION}

Zhu Huashan, the deputy director of Yunnan Provincial Education Department, pointed out in his Speech Addressing to Leading Cadres of the Provincial-Level Universities that Yunnan higher education should voluntarily serveand be involvedin the national development, highlight the schoolingfeatures, focus on its innovative leading role, activelyundertake the mission of Yunnan's opening up towards Southwestern areas. The higher education in Yunnan should try its best to construct the highland catering to Southwestern areas by updating the talent cultivation concept, reforming the talent cultivation mechanism, optimizing the talent growth environment and strengthening the intelligence service platform. The internationalization of cross-border talentcultivation in YUFE is a vivid case of the reform and innovation of higher education in Yunnan based on the Neighborhood Partnership Strategy. After several years of construction and development, the internationalization of cross-border talent cultivation modeadopted by YUFE has manifestedYunnan highereducation'sforward-lookingconcepts, regional advantages and labor market-oriented cultivation modes. YUFE has made a positive attempt in setting up clear cultivation objectives, combining foreign and domestic educational resources and cultivatinginternationalized and applied professional talents.

The quality and efficiency of the internationalized cultivation of talents in YUFE has become increasingly prominent, its pioneering concepts and reform or innovation measures will have a good role model for cross-border talent cultivation in other higher education institutions located at the international or regional economic center.

\section{REFERENCES}

[1] J.D.Yi, "Practice and reflection on innovative talent training mode,"Journal of National Academy of Education Administration, vol. 4, 2009, pp. 7-9.

[2] Z.H.Lu, "ASEAN trade giving momentum to minor languages talents, bottleneck of transformation from learning to application needs to be broken through,"Yunnan Law News, December 2010.

[3] Y.F.Shaoand B.L.Yi,"Postgraduate education internalization and enhancement of the quality,"Academic Degrees \& Graduate Education, supplementary issue, 2008, pp. 29-33.

[4] The Compiling group,"China academic degree and graduate education development strategy report,"Academic Degrees \& Graduate Education, Vol. 6, 2002, pp. 1-20.

[5] Yunnan University of Finance and Economics, "An Application Form ofAdditional Professional Master Degree Accreditation,”Internal Document, unpublished, 2013.

[6] Yunnan University of Finance and Economics, "A Selection of Overseas Internship of International Business Research Reports," Internal Document, unpublished, 2014.

[7] Yunnan University of Finance and Economics, "An Application Form of Master-degree Program of International Business in Developing Countries sponsored by the Ministry of Commerce of China," Internal Document, unpublished, 2014. 